\title{
A new species of freshwater crab genus Fredius Pretzmann, 1967 (Crustacea: Brachyura: Pseudothelphusidae) from a naturally isolated orographic forest enclave within the semiarid Caatinga in Ceará, northeastern Brazil
}

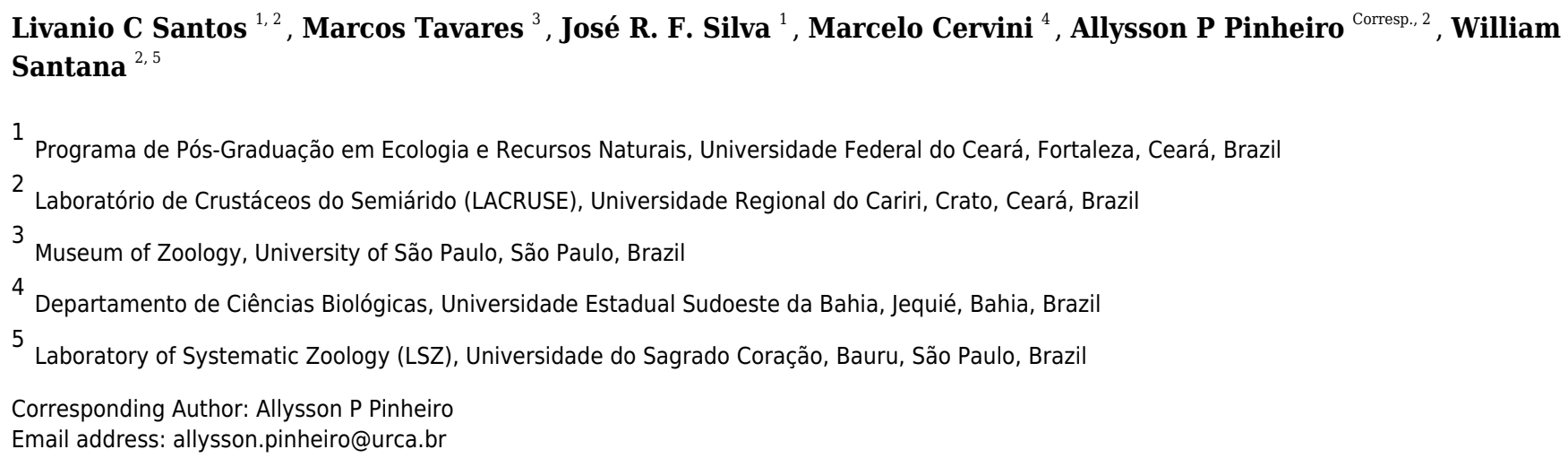

A new species of freshwater crab, Fredius ibiapaba, is described and illustrated from a midaltitude forested patch in Ipú (Ibiapaba plateau, Ceará, northeastern Brazil), between 635 to $782 \mathrm{~m}$. The new species can be separated from its congeners by the morphology of its first gonopod: proximal half remarkably swollen, sloping abruptly downwards distally to a nearly right-angular shoulder; mesial lobe much smaller than cephalic spine; cephalic lobe moderately developed; auxiliary lobe lip, delimiting field of apical spines, protruded all the way to distal margin of auxiliary lobe. Comparative 16S rDNA sequencing used to infer the phylogenetic placement of Fredius ibiapaba n. sp. revealed that it is the sister taxon of $F$. reflexifrons, a species which occurs allopatrically in the Amazon and Atlantic basin's lowlands $(<100 \mathrm{~m}$ ). Fredius ibiapaba n. sp. and F. reflexifrons are highly dependent upon humidity and most probably were once part of an ancestral population living in a wide humid territory. Shrinking humid forests during several dry periods of the Tertiary and Quaternary likely have resulted in the fragmentation of the ancestral humid area and hence of the ancestral crab population. Fredius reflexifrons evolved and spread in a lowland, humid river basin (Amazon and Atlantic basins), whilst F. ibiapaba n. sp. evolved isolated on the top of a humid plateau. The two species are now separated by a vast intervening area occupied by the semiarid Caatinga 
1 A new species of freshwater crab genus Fredius Pretzmann, 1967 (Crustacea: Brachyura:

2 Pseudothelphusidae) from a naturally isolated orographic forest enclave within the 3 semiarid Caatinga in Ceará, northeastern Brazil

Livanio C. Santos ${ }^{1,2}$, Marcos Tavares ${ }^{3}$, José Roberto Feitosa Silva², Marcelo Cervini ${ }^{4}$, Allysson P. Pinheiro ${ }^{*}$, William Santana ${ }^{1,5}$

${ }^{1}$ Laboratório de Crustáceos do Semiárido (LACRUSE), Universidade Regional do Cariri,

Crato,Ceará, Brazil. ORCID: 0000-0003-1565-6371. E-mail: allysson.pinheiro@urca.br.

2 Programa de Pós-Graduação em Ecologia e Recursos Naturais, Universidade Federal do

Ceará, Fortaleza, Ceará, Brazil. E-mails: robertofeitosa@ufc.br and santos.bio.79@gmail.com

${ }^{3}$ Museum of Zoology, University of São Paulo, São Paulo, Brazil. ORCID: 0000-0002-7186-

5787 5. E-mail: mdst@usp.br

${ }^{4}$ Departamento de Ciências Biológicas, Universidade Estadual Sudoeste da Bahia, Jequié,

Bahia, Brazil. E-mail: marcelo_cervini@yahoo.com.br

${ }^{5}$ Laboratory of Systematic Zoology (LSZ), Universidade do Sagrado Coração, Bauru, São

Paulo, Brazil. ORCID: 0000-0003-3086-4419. E-mail: willsantana@gmail.com

19

Corresponding Author:

Allysson P. Pinheiro

Rua Cel. Antônio Luis, 63100-000, Crato-CE, Brazil

Email address: allysson.pinheiro@urca.br

\section{Abstract}

A new species of freshwater crab, Fredius ibiapaba, is described and illustrated from a midaltitude forested patch in Ipú (Ibiapaba plateau, Ceará, northeastern Brazil), between 635 to 782 $\mathrm{m}$. The new species can be separated from its congeners by the morphology of its first gonopod: proximal half remarkably swollen, sloping abruptly downwards distally to a nearly right-angular shoulder; mesial lobe much smaller than cephalic spine; cephalic lobe moderately developed; auxiliary lobe lip, delimiting field of apical spines, protruded all the way to distal margin of auxiliary lobe. Comparative $16 \mathrm{~S}$ rDNA sequencing used to infer the phylogenetic placement of Fredius ibiapaba n. sp. revealed that it is the sister taxon of $F$. reflexifrons, a species which occurs allopatrically in the Amazon and Atlantic basin's lowlands (<100 m). 
35 Fredius ibiapaba n. sp. and F. reflexifrons are highly dependent upon humidity and most probably were once part of an ancestral population living in a wide humid territory. Shrinking humid forests during several dry periods of the Tertiary and Quaternary likely have resulted in the fragmentation of the ancestral humid area and hence of the ancestral crab population. Fredius reflexifrons evolved and spread in a lowland, humid river basin (Amazon and Atlantic basins), whilst $F$. ibiapaba n. sp. evolved isolated on the top of a humid plateau. The two species are now separated by a vast intervening area occupied by the semiarid Caatinga.

\section{Introduction}

Cumulative evidence from many independent sources argue in favor of the mid-altitude forested patches in northeastern Brazil being remnants of a once much larger humid forest, connected to both the Amazonian and Atlantic rainforests during the moister periods (e.g., Andrade-Lima, 1982; Cartelle \& Hartwig, 1996; de Vivo, 1997; Ab'Saber, 2000; Auler et al., 2004; Carnaval \& Bates, 2007; Carmignotto, 2012; and references therein). These humid forest refuges (Figure 1A-D), naturally isolated by the vast surrounding semiarid Caatinga (Figure 1F, G), are indeed known to harbor many woody plant and animal species (fossil and Recent) that are also found or are closely related to species occurring allopatrically in the Amazonian and Atlantic rainforests.

Here we describe and illustrate a new species of a freshwater pseudothelphusid crab, Fredius ibiapaba n. sp., from a humid forest refuge in Ipú (Ibiapaba plateau, Ceará, northeastern Brazil), between 665 to 782 m (Figure 1A-D). Evidence from a phylogenetic analysis using $16 \mathrm{~S}$ rDNA is presented for a sister taxa relationship between Fredius ibiapaba $\mathrm{n}$. sp. and F. reflexifrons (Ortmann, 1897), a species occurring allopatrically in the Amazonian humid lowlands. Previous hypothesis on the phylogenetic relationships of $F$. reflexifrons and the possible evolutionary scenario that led to the emergence of the sister taxa Fredius ibiapaba $\mathrm{n}$. sp. and $F$. reflexifrons are discussed.

\section{Materials \& Methods} Procedures with material examined 
The specimens were collected using license permission from the Sistema de Autorização

65

66

67

68

69

70

71

72

73

74

75

76

77

78

79

80

81

82

83

84

85

86

87

88

89

e Informação em Biodiversidade (SISBIO \#29615) of the Brazilian Ministry of Environment

(MMA). The studied specimens are deposited in the collections of the INPA (Instituto Nacional

de Pesquisas da Amazônia, Manaus), MZUSP (Museu de Zoologia, Universidade de São

Paulo, Brazil) and LACRUSE (Laboratório de Crustáceos do Semiárido). Other acronyms: SMF

(Naturmuseum Senckenberg) and CCDB (Coleção de Crustáceos do Departamento de Biologia da Faculdade de Filosofia, Ciências e Letras de Ribeirão Preto). Measurements: cl (carapace

length, taken along the carapace axis to the posterior median margin) and cw (carapace width, taken at the widest point), in millimeters $(\mathrm{mm})$. Dates are written in the format day.month.year, with months in lower-case Roman numerals. Abbreviations are as follows: G1, G2, first and second gonopods, respectively. Mxp3, third maxilliped. The terminology used in the description of the G1 essentially follows (Rodríguez \& Pereira, 1992; Rodríguez \& Campos, 1998) (Figure 2).

\section{Molecular data analysis}

DNA extraction, amplification and sequencing: Muscle tissue samples were obtained from the pereopods or pleon of Fredius ibiapaba n. sp., F. buritizatilis Magalhães \& Mantellato in Magalhães et al., 2014, and Prionothelphusa eliasi Rodriguez, 1980. At the Laboratório de Biologia Molecular da Universidade Estadual do Sudoeste da Bahia- LBM/UESB a small region of the $16 S$ rDNA gene was extracted with Wizard® Genomic DNA Purification Kit (Promega), amplified in a 12,5 $\mu \mathrm{l}$ final volume reaction with 2,5 $\mathrm{mM}$ de $\mathrm{MgCl} 2$ (Invitrogen), 0,05 $\mathrm{mM}$ de dNTP (Invitrogen), buffer 1x (Invitrogen - 10xPCR Buffer: 200mM Tris-HCl (pH 8.4), 500mM $\mathrm{KCl}$ ), $1 \mathrm{U}$ de taq platinum (Invitrogen) and $0,3 \mu \mathrm{M}$ of each primer. The PCR conditions were: one cycle at $94^{\circ} \mathrm{C}, 60 \mathrm{sec}$; five cycles at $94^{\circ} \mathrm{C}, 60 \mathrm{sec} ; 45^{\circ} \mathrm{C}, 40 \mathrm{sec}$ and $72^{\circ} \mathrm{C}, 60 \mathrm{sec}$; and 35 cycles at $94^{\circ} \mathrm{C}, 60 \mathrm{sec} ; 51^{\circ} \mathrm{C}, 40 \mathrm{sec}$ and $72^{\circ} \mathrm{C} ; 60 \mathrm{sec}$; a final extension of five minutes at $72^{\circ} \mathrm{C}$ was performed. The primers used were 16Sar (5'-CCGGTCTGAACTCAGATCACGT-3') and

Peer] reviewing PDF | (2019:11:43401:2:0:NEW 8 May 2020) 
90

91

92 93 94

\section{Registration of nomenclatural act}

16Sbr (5'-CGCCTGTTTATCAAAAACAT-3') (Palumbi et al., 1991). PCR products were purified using a polietilenoglicol (PEG) 20\% and sequenced in an ABI Prism 3100 Genetic Analyzer® (Applied Biosystems) at the Departamento de Tecnologia da Universidade Estadual Paulista “Júlio de Mesquita Filho", Jaboticabal. Sequencing reaction was performed with Big Dye v3.1 (Applied Biosystems), prepared with 4,75 $\mu$ ultrapure water, 1,5 $\mu$ l BigDye 5x buffer, 0,75 $\mu \mathrm{l}$ BigDye terminator Mix, $2 \mu \mathrm{l}$ primer $(0,8 \mathrm{pmol})$ and $1 \mu \mathrm{l}$ of Purified PCR product. Sequence conditions were: one minute at $96^{\circ} \mathrm{C} ; 35$ cycles of $15 \mathrm{sec}$ at $96^{\circ} \mathrm{C} ; 15 \mathrm{sec}$ at $50^{\circ} \mathrm{C}$ and 2 minutes at $60^{\circ} \mathrm{C}$. Both, forward and reverse sequence strands were obtained and the consensus generated by the software BioEdit 7.0.5 (Hall, 2005). The identities of the final sequences were confirmed with a BLAST (Basic Local Alignment Search Tool) on GenBank database. Additional comparative sequences were retrieved from GenBank (Table 1).

Phylogenetic analyses: Substitution saturation in 16S rDNA was tested using the saturation index implemented in DAMBE 5 (Xia, 2013). The sequences were grouped and edit in BioEdit and aligned using the ClustalW interface (Thompson et al. 1994). Prionothelphusa eliasi (Pseudothelphusidae) and Trichodactylus dentatus H. Milne Edwards, 1853 (Trichodactylidae) were chosen as outgroups. The best-fit model HKY + G was selected using jModeltest 2.1.7 (Darriba et al., 2012). This model was used to generate Maximum Likelihood gene trees in MEGA 6.06 (Tamura et al. 2013). Branch support values were calculated using bootstrap analyses with 1,000 replicates (Felsenstein, 1985). Only nodes with bootstrap support greater than 50 are shown on the phylogenetic tree. Nucleotide divergence estimated from pairwise distance was calculated in MEGA 6.06 with the same best-fit model (Table 2).

The electronic version of this article in Portable Document Format (PDF) will represent a published work according to the International Commission on Zoological Nomenclature (ICZN), and hence the new names contained in the electronic version are effectively published under 
116 that Code from the electronic edition alone. This published work and the nomenclatural acts it

117 contains have been registered in ZooBank, the online registration system for the ICZN. The

118 ZooBank LSIDs (Life Science Identifiers) can be resolved and the associated information

119 viewed through any standard web browser by appending the LSID to the prefix

120 http://zoobank.org/. The LSID for this publication is: [urn:Isid:zoobank.org:pub:0925982D-7441-

121120 4256-9856-A553987956A6]. The online version of this work is archived and available from

122 the following digital repositories: PeerJ, PubMed Central and CLOCKSS.

123

124

\section{Results}

125 Family Pseudothelphusidae Ortmann, 1893

126 Genus Fredius Pretzmann, 1967

127 Fredius ibiapaba n. sp. (Figures 3A-E; 4A-C; 5A, C; 6A-D; 7A-E)

128 Fredius reflexifrons - Magalhães et al., 2005: 94, fig. 1 - Santos et al., 2020: 3.

129

130 Type material. Holotype, Ceará, Ipú, Sítio Caranguejo, 04¹8'50" S, 4044'47"W, 729 m, 131 xii.2017, male cl 36 mm, cw 53mm (MZUSP 39710). Paratypes: Same data as holotype, male cl 13234 mm, cw 48 mm (MZUSP 39169); Ceará, Ipú, Sítio Gameleira, 04¹7'17" S, 4044'44"W, 665 m, 5.i.2018, female cl 35 mm, cw 49 mm (MZUSP 39171); Ceará, Ipú, Sítio Santa Cruz, Ipú, Sítio Santa Cruz, 04¹9'40" S, 4045'09"W, 782 m, 23.iv.2015, female cl 31 mm, cw 44 mm (MZUSP 39168); Ceará, Ipú, Sítio Ipuçaba, 798m, 27.xii.2017, male cl 41.2 mm, cw 62.6 mm (MZUSP 39742). Ceará, Ipú, Sítio Gameleira, quintal do Kindó, 04¹7'42"S, 4044'43" W, L.C. 138 Cruz, J.G. Araújo, H.S. Mattos and J.E.P Araújo coll., 665 m, 01.v.2018, 3 males, cl 35.5 mm, 139 cw 52.2 mm, cl 37.7 mm, cw 56.6 mm, cl 32.2 mm, cw 46.6 mm (LACRUSE 259). Ceará, Ipú, 140 Sítio Santa Cruz, 04019'40"S 4045'09"W, L.C. Cruz coll., 782 m, 23.iv.2015, 2 males, cl 28.7 
$141 \mathrm{~mm}$, cw $42.4 \mathrm{~mm}$, cl $31.5 \mathrm{~mm}$, cw $46.0 \mathrm{~mm}$, 1 female, cl $37.7 \mathrm{~mm}$, cw 55,1 mm (LACRUSE 142 216).

143

144 Non-type material. Ceará, Viçosa do Ceará, Fonte do Caranguejo, 03³3’43.2"S, 415’09.6"W, 145 M. Pereira coll., 24. vi. 2004, 2 males (INPA 1382).

147 Comparative material. Fredius fittkaui (Bott, 1967): Guyana - Potaro-Siparuni, Rio Kuribrong, $14805^{\circ} 22^{\prime} 35^{\prime \prime N}, 59^{\circ} 33^{\prime} 4^{\prime \prime} W$, P. Bernardo and B. Newman coll., 28.ix.2010, male, cl $47.1 \mathrm{~mm}$, cw 14966.9 mm (MZUSP 24497). Fredius reflexifrons (Ortmann, 1897): Brazil - Amapá, Serra do 150 Navio, Serra do Veado, Projeto Diversitas Neotropica, M. Tavares coll. 7.v.1994, male, cl 37 151 mm, cw 52 m (MZUSP 19922). Amapá, Rio Jari, montante, Cachoeira Santo Antônio, M. Jegú 152 and J. Zuanon coll., 9-26.vi.1981, 2 males, cl 42 mm, cw 57.7 mm, and cl 53 mm, cw $73.8 \mathrm{~mm}$ 153 (MZUSP 13178). Amapá, Serra do Navio/ Serra do Veado, 07.v.1994, male (INPA 583).

154 Amapá, Laranjal, 16.i.2012, male (INPA 2125). Amazonas, Manaus, Reserva do Km 41, 155 02²6’56”S, 5946'13”W, male (INPA 889). Amazonas, Manaus, Reserva Ducke, 22.ii.1986, 156 male (INPA 368). Amazonas, Manaus, 11.vii.2001, male (INPA 850). Amazonas, Iranduba, Sítio 157 Anaíra, 0310’39”S, 6007’39”W, 12.ix.1999, male (INPA 852). Pará, Santarém, Com. Santa 158 Rosa, male (INPA 1254). Pará, Rio do Peixe Boi, 01¹1'30”S, 47¹8'54”W, E. Matos and A. 159 Henriques Jr coll., 03.iii.1995, male (INPA 851). Pará, Bragança, Rio Chumucuí, S. Alves coll., 160 12. xi. 2004, male (INPA 1512). Peru: Rio Apiacu, Departamento Loreto, Boris Malkin coll., 161 15-25.iv.1966, male, cl 31 mm, cw 42.5 mm (MZUSP 6389). Fredius denticulatus (H. Milne 162 Edwards, 1853): Brazil - Rio Amapari, Serra do Navio, AP, Projeto Diversitas Neotropica, n¹51, 163 M. Tavares coll., 30.iv.1994, C. Magalhães det. 16.ii.1996, male cl 45 mm, cw 62 mm (MZUSP 164 16294).

165

166 Type locality. Sítio Caranguejo, Ipú, Ceará, 04¹8'50"S, 4044'47"W, 729 m. 
168 Distribution. Currently known from Ipú, Ibiapaba plateau, Ceará, northeastern Brazil, in midaltitude forests between 665 to $798 \mathrm{~m}$.

170

171 Etymology. The specific epithet is a noun in apposition taken from the Tupi language word for 172 plateau, "yby'ababa", ibiapaba.

173

174 Diagnosis. G1 robust, proximal half remarkably swollen, sloping abruptly downwards anteriorly 175 to a nearly right-angular shoulder (Figure 4B, C); mesial lobe much smaller than cephalic spine 176 (Figures 4B, C; 5C, D; 7A, C, E); cephalic lobe somewhat broad, rounded apically (Figure 4A); 177 auxiliary lobe lip, delimiting field of apical spines, protruded all the way to distal margin of 178 auxiliary lobe (Figures 4A, B; 6B; 7D).

179

Description of the holotype. Carapace transversally ovate (Figure $3 \mathrm{~A}$ ), widest at midlength (cw/cl, 1.51); dorsal surface smooth, slightly convex, regions ill-defined. Gastric pits minute, very close to each other. Cervical grooves shallow, nearly straight, poorly indicated, distal ends reaching to anterolateral margin. Front deflexed, almost straight in dorsal view, entire, marked with row of very small granules; front lower border carinate, with an almost indistinct sinus medially in frontal view; postfrontal lobules obsolete; median groove between postfrontal lobules faint (Figure 3A, C). Upper orbital margin with row of very faint granules; lower margin minutely denticulate; exorbital angle marked by obtuse tooth, followed posteriorly by faint notch (Figure 3C). Carapace anterolateral margin semicircular in outline, fringed by minute denticles; posterolateral margins almost straight, strongly convergent, smooth (Figure 3A, C). Epistomial margin with minute granules; epistomial tooth broadly triangular, deflexed (Figure 3C).

191 Suborbital and subhepatic regions of carapace smooth; pterygostomial region densely 192 pubescent around buccal cavity (Figures 3B, C). 
Mxp3 palp slender, long, reaching slightly beyond articulation of merus and ischium when

194 folded. Merus markedly operculiform. Posterior half of mesial margin of merus and mesial 195 margin of ischium with conical teeth (Figure 3C). Exopod short, 0.28 times length of lateral 196 margin of ischium, devoid of flagellum. Efferent branchial channel opening subcircular (Figure $1973 C)$.

198 Chelipeds moderately heterochelous, right cheliped larger than left one (Figure 3E, F).

199 Major cheliped merus subtriangular in cross-section; lateral surface smooth, with irregular row of 200 small tubercles of different sizes along dorsal surface; mesial surface smooth, slightly concave 201 to fit lateral sides of carapace; mesial lower margin with row of conical teeth slightly increasing 202 in size distally; lateral lower margin with row of small teeth. Carpus smooth dorsally; mesial 203 margin with row of small, irregular teeth and strong, acute spine about midlength of margin. 204 Palm moderately swollen, smooth on lateral and mesial surfaces, with minute granules on 205 rounded dorsal and ventral faces. Dactylus in process of regeneration. Cutting margin of 206 dactylus and fixed finger both with larger teeth interspersed with smaller ones. Fingers not gaping when closed, tips not crossing. Minor cheliped similar in shape.

Thoracic sternal suture 2/3 complete, distinct; sternal suture 3/4 interrupted, visible only laterally (Figure 3B); sternal sutures 4/5and 5/6 interrupted, ending just before reaching midline of thoracic sternum; sternal sutures $6 / 7$ and $7 / 8$ complete. Midline of thoracic sternum deeply 211 incised in sternites VII and VIII.

212 All pleonal segments free. Lateral margins of male telson slightly concave, tip rounded 213 (Figure 3B).

214 G1 robust (Figures 4A-C), proximal half remarkably swollen, sloping abruptly downwards 215 distally to a nearly right-angular shoulder (Figure 4B, C). Subapical bulge moderately developed 216 around lateral and sternal sides (Figures 4B; 5A, B; 6A). Marginal suture straight (Figure 4C). 217 Marginal lobe truncate, projected distally beyond pleonal surface, junction with marginal lobe 218 marked by distinct depression. Mesial lobe much smaller than cephalic spine, showing as 
219 triangular, acute spine, pointing to pleonal direction (Figures 4A, C, 5B; C; 6A, C). Cephalic 220 spine very strong, acuminate at tip, pointing to mesial direction (Figures 4A-C, 5B; C; 6A-C).

221 Cephalic lobe prominent, blunt, tip rounded, with several spinules along lateral, mesial and 222 sternal sides (Figures 4A, B; 6A, B). Auxiliary lobe much shorter than cephalic lobe in pleonal 223 view, separated from it by distinct depression, their junction forming lateral channel running 224 distally in almost straight direction before ending in inward curve subterminally (Figures 4A; 6A).

225 Field of apical spines large, open, flattened, elongated, ear-shaped, provided with small 226 spinules, delimited by lateral and pleonal lips of apex (Figures 4A, B; 5B; 6A, B). G2 slightly longer than G1; very slender, tapering distally progressively, distal part moderately flattened, with somewhat dense, minute spinules along sternal side.

229

Remarks. Fredius ibiapaba n. sp. is herein assigned to the genus Fredius, whose diagnostic characters (Rodriguez, 1982; Rodriguez \& Pereira, 1992) are readily recognized in the new species, namely, exopod of mxp3 short, about 0.3 times length of outer margin of ischium with G1 widest at base (Figure 4B, C); marginal lobe simple, ending in an inverted cup-shaped elongation at base of field of apical spines; subapical bulge covering lateral and sternal sides; field of apical spines large, open, flattened, ear-shaped, with small scattered spinules at proximal sternal border (Figures 4A-C; 5B; 6A, B). reflexifrons and F. ykaa Magalhães, 2009, in that the gonopod cephalic spine is much more developed than the mesial lobe (see Magalhães \& Rodríguez, 2002: 679, fig. 1; 683, fig. 2 , respectively; Rodríguez \& Campos, 1998: 766, fig. 2O, P) (Figure 4A, C; 5B; 6A, C), whereas 241 other species either have the gonopod cephalic spine little larger than the mesial lobe $(F$. 242 stenolobus Rodríguez \& Suárez, 1994, and F. adpressus Rodríguez \& Pareira, 1992), or have it 243 much shorter than the mesial lobe (e.g., F. buritizatilis, F. platyacanthus Rodríguez \& Pereira, 244 1992, and F. estevi Rodriguez, 1966), or have the cephalic spine and the mesial lobe similar in 
245 size (e.g., F. granulatus Rodríguez \& Campos, 1998, and F. chaffanjoni Rathbun, 1905) (see

246 Magalhães et al., 2014 and references therein).

247 Fredius ibiapaba n. sp. stands apart from Fredius denticulatus, F. fittkaui, F. reflexifrons 248 and $F$. ykaa in having the G1 proximal half remarkably swollen on the pleonal side, sloping 249 abruptly downwards distally to a nearly right-angular shoulder (Figures 4B, C), whereas in the 250 latter four species the G1 shoulder is clearly more gently sloping distally (Figure 4E, F).

$251 \quad$ Fredius ibiapaba n. sp. closely resembles F. reflexifrons, but the following characters 252 derived from G1 distinguish the new species from the latter species: (1) in having the auxiliary 253 lobe lip, delimiting the field of apical spines, protruded all the way to the distal margin of the 254 auxiliary lobe (Figure 4A, B), whereas in F. reflexifrons the lip fades away well before reaching 255 the distal margin of the lobe (Figure 4D, E); (2) the subapical bulge markedly less swollen 256 (Figures 5A, C) and the G1 apex much less tilted so that the mesial lobe is not visible in sternal 257 view (Figure 5A), in contrast to F. reflexifrons (Figures 5B, D, respectively). Also, in F. ibiapaba $258 \mathrm{n}$. sp. the distal margin of the cephalic lobe is blunt (Figure 4A, 6A), whereas in F. reflexifrons it 259 tapers progressively to a distinct narrower tip (Figure 4D, 6D).

260 Fredius ibiapaba n. sp. further differs from F. ykaa in that the G1 shoulder is high and 261 robust (Figures 4B, C), whilst in F. ykaa the G1 shoulder is remarkably lower; it can be easily 262 further differentiated from $F$. denticulatus in that its $G 1$ caudal lobe lacks a field of spines spirally 263 twisted to a transverse position (viz., Rodríguez \& Campos, 1998) and from F. fittkaui in having 264 the G1 cephalic spine straight and sharply acuminate, whereas in F. fittkaui it is curved and 265 round tipped. Morphological differentiation between female specimens is difficult.

\section{Discussion}

\section{Phylogenetic analysis}

269 The mitochondrial loci $16 S$ was successfully amplified and sequenced for Fredius buritizatilis, $F$. 270 ibiapaba n. sp., and Prionothelphusa eliasi. Additional sequences used were retrieved from 
271 GenBank (Table 1). Bootstrap support values are shown on nodes of the phylogenetic tree

272 (Figure 8). The sister species relationships between Fredius reflexifrons and the new species is 273 well supported by high bootstrap value. The close morphological similarity between the two 274 species also supports such relationship.

275 The divergence rates between Fredius reflexifrons and F. ibiapaba n. sp. (4\%) is higher 276 than between $F$. estevisi $\times$ F. stenolobus, $F$. platyacanthus $\times$ F. stenolobus and $F$. platyacanthus $277 \times$ F. estevisi all with $2 \%$ of divergence (Table 2). Morphology and molecular data hence provide 278 evidences for the differentiation between F. ibiapaba n. sp. and F. reflexifrons.

279 A survey of the pseudothelphusids described from 1840 to 2004 (Yeo et al., 2008) 280 showed that the curve of described species is still far from being asymptotic. And indeed, new 281 species are still being discovered either by collecting in new biomes (e.g., F. buritizatilis from a palm swamp known as "buritizal"), or by revisiting the taxonomy of widely disjunct species for testing as to their conspecific identity, such as F. ibiapaba n. sp. and F. reflexifrons.

284

\section{Zoogeographical notes}

Fredius currently consists of 14 species (Table 3), distributed over a vast territory, which encompass five main river basins (Rodríguez \& Campos, 1998; Magalhães et al., 2014): (1) the Orinoco River basin; (2) the Essequibo-Cuyuni River basin; (3) the Amazon River basin; (4) the Madeira River basin and its tributary (Machado River); and (5) the Atlantic rivers basin, a coastal drainage of small rivers in northern South American (Guyana, Suriname and French Guiana) discharging directly into the Atlantic Ocean. adpressus was presumably supported by three putative synapomorphies: (1) [G1] mesial lobe attached to back of auricular lobe; (2) basal denticle of mesial lobe present; and (3) subapical bulge well developed. 

new analysis in which they decided that character 1 (mesial lobe attached to back of auricular lobe) was no longer tenable and hence was eliminated from the new analysis. They also realized that the basal denticle of the mesial lobe was indeed present in F. adpressus (character 2), but was absent in all other Fredius species. They further concluded that the subapical bulge was actually "reduced" in F. adpressus and "strongly developed" in F. granulatus, $F$. reflexifrons, $F$. fittkauii, and $F$. denticulatus, so that these latter two characters were also removed from the new analysis. Therefore, the putative sister taxon relationship between $F$. reflexifrons and F. adpressus dissolved. Rodriguez \& Campos (1998) put forward, instead, the hypothesis that $F$. reflexifrons was sister to $F$. fittkauii, not to $F$. adpressus, based on the assumption that $F$. reflexifrons and $F$. fittkauii synapomorphically share the cephalic lobe distal margin armed with several spinules. However, as found here, this character is more widely distributed being also found in F. ibiapaba n. sp. and, therefore, cannot be used to argue for the sister taxon relationship between $F$. reflexifrons and $F$. fittkauii. Magalhães et al. (2014) performed a distance analysis based on 16S rRNA, in which $F$. reflexifrons was recovered as the sister taxa to ( $F$. fittkauii $(\mathrm{F}$. denticulatus (F. granulatus ( $F$. buritizatilis (F. platyacanthus (F. denticulatus (F. stenolobus $)))$ )))). The discovery of $F$. ibiapaba n. sp. revealed, however, that it is actually the sister taxa of F. reflexifrons, as shown by a comparative 16S rDNA sequencing used to infer the phylogenetic placement of Fredius ibiapaba n. sp., with F. fittkauii recovered as the sister taxa to the remaining species (Figure 8). The distribution range of Fredius ibiapaba n. sp. is very narrow and currently restricted to 318 a humid enclave, a small mid-altitude forested patch in Ipú (Ceará, northeastern Brazil, Figure 1A-E), nested within the vast semiarid Caatinga domain (Figure 1F, G). The orographic forest enclaves, such as Ipú, are typically located along the slopes of plateaus, between 600 and 1100

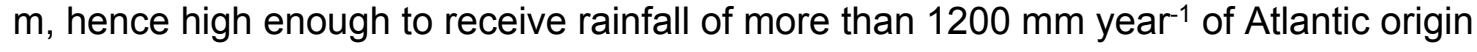

322 (Tabarelli et al., 2004 and references therein). These enclaves are regionally known as "Brejos" 
323 (or "Brejos de altitude" or even "Brejos nordestinos") (Andrade-Lima, 1982; Silva \& Casteletti, 324 2003; Tabarelli \& Santos, 2004). Fredius ibiapaba n. sp. inhabits the mid-highlands of the 325 Ibiapaba plateau, between about 635 to $782 \mathrm{~m}$, where it digs burrows among the leaf litter, 326 alongside little streams and water ponds inside forest stands or directly on the humid forest floor 327 (Figure 1E). In contrast, F. reflexifrons is widely distributed in the Amazon basin's lowlands (< $328100 \mathrm{~m}$ ) from as far west as Peru (Ampyiacu River, a tributary of the Amazonas River) to as far 329 east as the Atlantic basin (French Guiana) (Magalhães, 2003). It is found in burrows alongside 330 the "igarapés" (streams) or digs its burrows on the humid forest floor (Magalhães \& Rodríguez, 331 2002). Magalhães et al. (2005) misidentified the specimens from the mid-highlands of the 332 Ibiapaba plateau with F. reflexifrons and explained its presence in Ibiapaba by a migration “...eastwards as far as Serra de Ibiapaba” during the expansion of the humid tropical forest. Fredius ibiapaba n. sp. and F. reflexifrons are highly dependent upon humidity and our view is that they most probably were once part of an ancestral population living in a wide humid territory. The shrinking humid forests during several dry periods of the Tertiary and Quaternary 337 (Katzer, 1933; Andrade-Lima, 1953; Bigarella et al., 1975; Ab'Saber, 1977; Bigarella \& AndradeLima, 1982; Andrade-Lima, 1982; Clapperton, 1993; Thomas, 2000; Haffer, 2001; Haffer \& Prance, 2002) likely have resulted in the fragmentation of the ancestral humid area and hence of the ancestral crab population, which was split into two sister species. Fredius reflexifrons evolved and spread in a lowland, humid river basin and is now widely distributed, whilst $F$. ibiapaba n. sp. evolved isolated on the top of a humid plateau (Figure 1A-E). The two species are now separated by a vast intervening area occupied by the semiarid Caatinga (Figure 1F, G). The expansion and shrinkage of mountain, floodplain, and gallery forests, associated to complex topography are known to have affected flora and fauna (Vanzolini, 1970; Vanzolini \& Williams, 1970; Vuilleumier, 1971; Andrade-Lima, 1982; Teixeira et al., 1986; Haffer, 1969;

347 2001; Haffer \& Prance, 2002; Santos et al., 2007; Leite et al., 2016). Andrade-Lima (1982)

348 provided a number of examples of plant species that are now confined to the Brejos, isolated 
349 from the surrounding, widely distributed Caatinga. He found two floristic components in these

350 refuges on the top of hills, one whose species and genera have mostly originated from the

351 southeastern flora, lies further inland in the states of Alagoas and Rio Grande do Norte; and a

352 second one in the humid mid highlands closer to the coast, especially between Pernambuco

353 and the border of Ceará and Piauí states (referred to as the Pernambuco Centre by Santos et

354 al., 2007), in which the Amazonian flora are better represented (Andrade-Lima, 1982). Santos et

355 al. (2007) found strong bootstrap support for a close floristic relationship between the

356 Pernambuco Centre and Amazonian localities.

357 It has long been known that a number of freshwater fish species inhabiting the Brejos

358 have their closest relationships with those from the Amazonian Basin (Géry, 1969; Paiva, 1978;

359 Weitzman \& Weitzman, 1982; Ploeg, 1991; Vari, 1991; Menezes, 1996; Rosa \& Groth, 2004).

360 More recently, Pinheiro \& Santana (2016) described a new species of freshwater crab genus

361 Kingsleya Ortmann, 1897 (also a Pseudothelphusidae), from a Brejo about 750 m in Arajara

362 district, municipality of Barbalha, Ceará. Previously to their discovery Kingsleya was known from

363 nine species inhabiting the Amazonian lowlands (Pedraza \& Tavares, 2015).

364

\section{Acknowledgements}

366 We are thankful to Célio Magalhães (Instituto Nacional de Pesquisas da Amazônia) and Rafael

367 Lemaitre (National Museum of Natural History, Smithsonian Institution) for granting access to

368 their respective collections. We are in debt with Waltécio de Oliveira Almeida (Universidade

369 Regional do Cariri) for providing access to optical equipment and laboratory space and to

370 Jessica Colavite (Universidade Estadual Paulista "Júlio de Mesquita Filho") for the help during

371 figure preparations. This work greatly benefited from the comments of Célio Magalhães,

372 Tomoyuki Komai (Natural History Museum and Institute, Chiba) and an anonymous reviewer.

373

374 


\section{References}

376 Ab'Saber, A. N. (1977). Espaços ocupados pela expansão dos climas secos na América do Sul, 377 por ocasião dos períodos glaciais quaternários. Paleoclimas, 3, 1-19.

378 Ab'Saber, A. N. (2000). Spaces occupied by the expansion of bry climates in South America 379 during the Quaternary ice ages. Revista do Instituto Geológico, 21(1-2), 71-78.

380 Andrade-Lima, D. D. (1953). Notas sobre a dispersão de algumas espécies vegetais no Brasil. $381 \quad$ Anais da Sociedade de Biologia de Pernambuco, 11(1), 25-49.

382 Andrade-Lima, D. (1982) Present day forest refuges in northeastern Brazil. Biological 383 diversification in the tropics (ed. by G.T. Prance), pp. 245-254. Columbia University Press, $384 \quad$ New York.

385

386

387

388

389

390

391

392

393

394

395

396

397

398

399

400

Auler, A. S., Wang, X., Edwards, R. L., Cheng, H., Cristalli, P. S., Smart, P. L., \& Richards, D. A. (2004). Quaternary ecological and geomorphic changes associated with rainfall events in presently semi-arid northeastern Brazil. Journal of Quaternary Science, 19(7), 693-701.

Bigarella, J. J. \& Andrade-Lima, D. (1982). Paleoenvironmental changes in Brazil. Biological diversification in the tropics (ed. by G.T. Prance), pp. 27-40. Columbia University Press, New York.

Bigarella, J. J., Andrade-Lima, D. \& Riehs, P. J. (1975). Considerações a respeito das mudanças paleoambientais na distribuição de algumas espécies vegetais e animais no Brasil. Anais da Academia Brasileira de Ciências, 47, 411-464.

Carmignotto, A. P., de Vivo, M. D., \& Langguth, A. (2012). Mammals of the Cerrado and Caatinga: distribution patterns of the tropical open biomes of Central South America. Bones, clones and biomes. The history and geography of recent Neotropical mammals (BD Patterson and LP Costa, eds.). University of Chicago Press, Chicago, Illinois, 307-350.

Carnaval, A. C., \& Bates, J. M. (2007). Amphibian DNA shows marked genetic structure and tracks Pleistocene climate change in northeastern Brazil. Evolution: International Journal of Organic Evolution, 61(12), 2942-2957. 
401 Cartelle, C., \& Hartwig, W. C. (1996). A new extinct primate among the Pleistocene megafauna 402 of Bahia, Brazil. Proceedings of the National Academy of Sciences, 93(13), 6405-6409.

403 Clapperton, C. M. (1993). Nature of environmental changes in South America at the Last Glacial 404 Maximum. Palaeogeography, palaeoclimatology, palaeoecology, 101(3-4), 189-208.

405 Cumberlidge, N., Alvarez, F., \& Villalobos, J. L. (2014). Results of the global conservation 406 assessment of the freshwater crabs (Brachyura, Pseudothelphusidae and 407 Trichodactylidae): The Neotropical region, with an update on diversity. ZooKeys, (457), 133. 408 Darriba, D., Taboada, G. L., Doallo, R., \& Posada, D. (2012). jModelTest 2: more models, new 409 heuristics and parallel computing. Nature methods, 9(8), 772.

410 de Vivo, M. (1997). Mammalian evidence of historical change in the Caatinga semiarid 411 vegetation of northeastern Brazil. Journal of Comparative Biology, 2(1): 65-73.

412 Felsenstein, J. (1985). Confidence limits on phylogenies: an approach using the bootstrap. $413 \quad$ Evolution, 39(4), 783-791.

414 Géry, J. (1969). The freshwater fishes of South América. Pp. 828-848, in: Fitkau, E.J. et al. 415 (eds.) Biogeography and ecology in South America. Dr. W. Junk, The Hage.

416 Haffer, J. (1969). Speciation in Amazonian forest birds. Science, 165:131-137.

417 Haffer, J. (2001). Hypotheses to explain the origin of species in Amazônia, p. 45-118. In: Vieira, 418 I.C.; Silva, J.M.C.; Oren D.C.; D'Incao, M.A. (orgs) Diversidsade biológica e cultural da 419 Amazônia. Belém, Museu Paraense Emílio Goeldi, 421 p.

420 Haffer, J., \& Prance, G. T. (2002). Impulsos climáticos da evolução na Amazônia durante o 421 Cenozóico: sobre a teoria dos Refúgios da diferenciação biótica. Estudos avançados, $422 \quad 16(46), 175-206$.

423 Hall, T. (2005). Bioedit biological sequence alignment editor. Version 7.0.4. Ibis Therapeutics, 424 Carlsbad.

425 Katzer, F. (1933) Geologia do Estado do Pará. Boletim do Museu Paraense Emílio Goeldi de 426 História Natural e Etnografia, 9, 1-270. 
427 Leite, Y. L. R., Costa, L. P., Loss, A. C., Rocha, R. G., Batalha-Filho, H., Bastos, A. C.,

428 Quaresma, V. S., Fagundes, V., Paresque, R., Passamani, M. \& Pardini, R. (2016).

429 Neotropical forest expansion during the last glacial period challenges refuge hypothesis.

$430 \quad$ Proceedings of the National Academy of Sciences, 113(4), 1008-1013.

431 Magalhães, C. (2003). Brachyura: Pseudothelphusidae Trichodactylidae, p. 143-297. In: Melo, 432 G.A.S. de (ed.) In: Melo, G.A.S. (Ed.), Manual de Identificação dos Crustáceos Decápodos 433 de Água Doce Brasileiros. São Paulo, Edições Loyola. 429 p.

434 Magalhães, C. (2009). A new species of freshwater crab of the genus Fredius Pretzmann, 1967 435 from the middle Amazon River basin, Brazil (Crustacea: Decapoda: Pseudothelphusidae). 436 Proceedings of the Biological Society of Washington, 122(1), 81-86.

437 Magalhães, C. \& Pereira, G. (2007). Assessment of the decapod crustacean diversity in the 438 Guayana Shield region aiming at conservation decisions. Biota Neotropica, 7(2), 111-124. 439 Magalhães, C. \& Rodríguez, G. (2002). The systematic and biogeographycal status of Fredius reflexifrons (Ortmann, 1897) and Fredius fittkauii (Bott, 1967) (Crustacea:

441 Brachyura:Pseudothelphusidae) from the Amazon and Atlantic Guianas River basins. Acta $442 \quad$ Amazonica, 32(4): 677-689.

443 Magalhães, C., Abrunhosa, F. A., Pereira, M. D. O., \& Melo, M. A. (2005). New records of 444 Fredius denticulatus ( $\mathrm{H}$. Milne-Edwards, 1853) and F. reflexifrons (Ortmann, 1897), and the 445 eastern limits of the distribution of pseudothelphusid crabs (Crustacea: Decapoda) in Brazil. $446 \quad$ Acta Amazonica, 35(1), 93-96.

447 Magalhães, C., Sanches, V. Q. A., Pileggi, L. G. \& Mantelatto, F. L. (2014). Morphological and 448 molecular characterization of a new species of Fredius (Decapoda, Pseudothelphusidae) 449 from Rondônia, southern Amazonia, Brazil, p. 101-114. In: Yeo, D.C.J.; Cumberlidge, N.; $450 \quad$ Klaus, S. (eds.) Advances in freshwater decapod systematics and biology. Crustacean 451 Monographs 19. Leiden, Brill. 296 p. 
452 Menezes, N. A. (1996). Methods for assessing freshwater fish diversity. Pp. 289-295 in: Bicudo, 453 C.E. de M. \& N.A. Menezes (eds.), Biodiversity in Brazil: a first approach. CNPq, São 454 Paulo.

455 Mora-Day, J., Magalhães, C. \& El Souki, M. (2009). Lista Sistemática de los 456 macroinvertebrados Colectados Durante el RAP Alto Cuyuní 2008, Estado Bolívar, 457 Venezuela. In Evaluación Rápida de la Biodiversidad de los Ecosistemas Acuáticos de la 458 Cuenca Alta del Río Cuyuní, Guayana Venezolana. Conservation International. 459 Paiva, M. P. (1978). Ictiofauna e as grandes represas brasileiras. Revista Dae, 38(116), 49-57. 460 Palumbi, S. R., Martin, A., Romano, S., McMillan, W. O., Stice, L. \& Grabowski, G. (1991). The 461 Simple Fool's Guide to PCR, Version 2. University of Hawaii Zoology Department, $462 \quad$ Honolulu, $45 \mathrm{pp}$.

463 Pedraza, M. \& Tavares, M. (2015). A new species of freshwater crab of the genus Kingsleya 464 Ortmann, 1897 (Crustacea: Brachyura: Pseudothelphusidae) from Amazonia, Brazil. 465 Zootaxa, 4032(4): 444-450.

466 Pinheiro, A. P. \& Santana, W. (2016). A new and endagered species of Kingsleyia Ortmann, 4671897 (Crustacea: Decapoda: Brachyura: Pseudothelphusidae) from Ceará, northeastern 468 Brazil. Zootaxa, 4171(2): 365-372.

469 Ploeg, A. (1991). Revision of the South American cichlid genus Crenicichla Heckel, 1840, with 470 descriptions of fifteen new species groups, phylogeny and biogeography (Pisces, 471 Perciformes, Cichlidae) (Doctoral dissertation, PhD Thesis, Universiteit van Amsterdam, $472 \quad$ Netherland).

473 Rodríguez, G. (1982). Les crabes d'eau douce d'Amerique. Famille des Pseudothelphusidae. $474 \quad$ Faune Tropicale, 22. ORSTOM, Paris. 224 p.

475 Rodríguez, G. \& Campos, M. R. (1998). A cladistic revision of the genus Fredius (Crustacea: 476 Decapoda: Pseudothelphusidae) and its significance to the biogeography of the Guianan 477 lowlands of South America. Journal of Natural History, 32(5), 763-775. 
478 Rodríguez, G. \& Pereira, G. (1992). New species, cladistic relationships, and biogeography of 479 the genus Fredius (Decapoda: Brachyura: Pseudothelphusidae) from South America. $480 \quad$ Journal of Crustacean Biology, 12(2), 298-311.

481 Rosa, R. S. \& Groth, F. (2004). Ictiofauna dos ecossistemas de brejos de altitude de 482 Pernambuco e Paraíba. Brejos de Altitude em Pernambuco e Paraíba: História Natural, 483 Ecologia e Conservação. Série Biodiversidade, 9, 201-210.

484 Santos, A. M. M., Cavalcanti, D. R., Silva, J. M. C. D. \& Tabarelli, M. (2007). Biogeographical 485 relationships among tropical forests in north-eastern Brazil. Journal of Biogeography, 34(3), $486 \quad 437-446$.

487 Santos, L. C., Nascimento, W. M., Matos, H. S., Pinheiro, A. P. \& Silva, J. R. F. 2020. The 488 distribution of the freshwater crab Fredius reflexifrons (Ortmann, 1897) (Brachyura, 489 Pseudothelphusidae) in an Environmental Protection Area of the Planalto da Ibiapaba, $490 \quad$ Northeastern Brazil. Anais da Academia Brasileira de Ciências, 92(1): e20180814. 491 Silva, J. M. C. \& Casteletti, C. H. M. (2003) Status of the biodiversity of the Atlantic Forest of 492 Brazil. The Atlantic Forest of South America: biodiversity status, threats, and outlook (ed. by 493 494 495 496 C. Galindo-Leal and I.G. Câmara), pp. 43-59. Center for Applied Biodiversity Science and Island Press, Washington, DC.

Suárez, H. (2015). Six new species of freshwater crabs from Pantepui, Venezuela (Crustacea: Decapoda: Pseudothelphusidae). Anartia, 25, 64-94 [2013].

Tabarelli, M. \& Santos, A. M. M. (2004). Uma breve descrição sobre a história natural dos brejos nordestinos. Brejos de Altitude em Pernambuco e Paraíba, História Natural, Ecologia e Conservação, 9, 17-24.

500 Tamura, K., Stecher, G., Peterson, D., Filipski, A. \& Kumar, S. (2013). MEGA6: Molecular 501 Evolutionary Genetics Analysis version 6.0. Molecular biology and evolution, 30(12), 2725502 2729. doi:10.1093/molbev/mst197 
503 Teixeira, D. M., Nacinovic, J.B. \& Tavares, M.S. (1986) Notes on some birds of northeastern

504 Brazil. Bulletin of the British Ornithologists' Club, 106, 70-74.

505 Thomas, M. F. (2000). Late Quaternary environmental changes and the alluvial record in humid $506 \quad$ tropical environments. Quaternary International, 72(1), 23-36.

507 Thompson, J. D., Higgins, D. G. \& Gibson, T. J. (1994). CLUSTAL W: improving the sensitivity 508 of progressive multiple sequence alignment through sequence weighting, position-specific 509 gap penalties and weight matrix choice. Nucleic acids research, 22(22), 4673-4680.

510 Vanzolini, P. E. (1970). Zoologia sistemática, geografia e a origem das espécies. Instituto de 511 Geografia, Universidade de São Paulo, 56 p. (Série Teses e Monografias, 3).

512 Vanzolini, P. E. \& Williams, E. E. (1970). South American anoles: Geographic differentiation and 513 evolution of the Anolis chrysolepis species group (Sauria, Iguanidae). Arquivos de Zoologia, $514 \quad$ 19: 1-298.

515 Vari, R. P. (1991). Systematics of the neotropical characiform genus Steindachnerina Fowler 516 (Pisces: Ostariophysi). Smithsonian Contributions to Zoology, 507, 1-118.

517 Vuilleumier, B. S. (1971). Pleistocene changes in the fauna and flora of South America. 518 Science, 173(3999), 771-780.

519 Weitzman, S. H. \& Weitzman, M. (1982). Biogeography and evolutionary diversification in the 520 Neotropical freshwater fishes, with comments on the refuge theory. Pp. 403-422, in:

521 Prance, G.T. (ed.) Biological Diversification in the Tropics. Columbia University Press, New $522 \quad$ York.

523 Xia, X. (2013). DAMBE5: a comprehensive software package for data analysis in molecular 524 biology and evolution. Molecular biology and evolution, 30(7), 1720-1728.

525 Yeo, D. C. J., Ng, P. K. L., Cumberlidge, N., Magalhães, C., Daniels, S. R. \& Campos, M. R. 526 (2008). Global diversity of crabs (Crustacea: Decapoda: Brachyura) in freshwater. $527 \quad$ Hydrobiologia, 595, 275-286. 
528 Zanetti, F., Castro, P. M. D. \& Magalhães, C. (2018). Freshwater crabs (Decapoda: Brachyura:

529 Pseudothelphusidae, Trichodactylidae) from the state of Roraima, Brazil: species

530 composition, distribution and new records. Nauplius, 26, 1-19. 


\section{Captions for the figures and tables}

532 Figure 1. (A-E) Mid-altitude, naturally isolated, humid forested patch nested within the vast 533 semiarid Caatinga domain. Sítio Caranguejo, Ipú, Ceará, 04¹8'50" S, 4044'47"W, 729 meters

534 high, type locality of Fredius ibiapaba n. sp. Note in (E) burrow (arrow) of Fredius ibiapaba n. sp. 535 among the leaf litter. (E-F) Lowland, surrounding semiarid Caatinga forest. (E) View from above 536 from Ipú. (F) Detail of a dry-stream channel.

537

538 Figure 2. (A-B) Semi-diagrammatic illustrations of the first male gonopod in pleonal and sternal 539 views, respectively, with the terminology used in the descriptions. cl, cephalic lobe; cs, cephalic 540 spine; fas, field of apical spines; mal, marginal lobe; mas, marginal suture; mel, mesial lobe; 541 sab, subapical bulge.

542

543 Figure 3. (A-D) Fredius ibiapaba n. sp., holotype, male cl 36 mm, cw 53mm (MZUSP 39710).

544 (A-B) Habitus, dorsal and ventral views, respectively. (C) Cephalothorax, frontal view. (D-E)

545 Right and left chelipeds in lateral view, respectively. Scales: A-E, $10 \mathrm{~mm}$.

546

547 Figure 4. (A-F) Right male first gonopod (G1) in pleonal (tilted left), lateral and mesial views 548 from A-C and D-F, respectively. (A-C) Fredius ibiapaba n. sp., holotype, male cl $36 \mathrm{~mm}$, cw 549 53mm (MZUSP 39710). (D-F) Fredius reflexifrons (Ortmann, 1897), male cl 73.8 mm, cw 53 $550 \mathrm{~mm}$ (MZUSP 13178). Note in (B, C) the $\mathrm{G} 1$ remarkably swollen, sloping abruptly downwards 551 anteriorly to a nearly right-angular shoulder (arrow), and in (E, F) the G1 shoulder clearly more 552 gently sloping distally (arrow). Scales: A-F, 2mm.

553

554 Figure 5. (A-D) Right male first gonopod (G1) in sternal and apical views from $A$ to $B$ and $C$ to 555 D, respectively. (A, C) Fredius ibiapaba n. sp., holotype, male cl 36 mm, cw 53mm (MZUSP 556 39710). (B, D) Fredius reflexifrons (Ortmann, 1897), male cl 73.8 mm, cw 53 mm (MZUSP 
557 13178). Note in $(A)$ and $(C)$ the $G 1$ apex much less tilted so that the mesial lobe is not visible in 558 sternal view (arrow), and the subapical bulge markedly less swollen (arrow), respectively. Note 559 the opposite in (B) and (D). Scales: A-B, $2 \mathrm{~mm}$; C-D, $1 \mathrm{~mm}$.

560

561 Figure 6. (A-H) Right male first gonopod (G1) in sternal, lateral, mesial, and pleonal views from 562 A-D and E-H, respectively. (A-D) Fredius ibiapaba n. sp., holotype, male cl $36 \mathrm{~mm}$, cw 53mm 563 (MZUSP 39710). (E-H) Fredius reflexifrons (Ortmann, 1897), male cl 73.8 mm, cw 53 mm 564 (MZUSP 13178). Scales: A-H, $1 \mathrm{~mm}$.

565

566 Figure 7. (A-E) Fredius ibiapaba n. sp., paratype, male cl $41.2 \mathrm{~mm}$, cw $62.6 \mathrm{~mm}$ (MZUSP 567 39742). Scanning electron microscopy of the first right male gonopod in mesial (tilted right), 568 sternal, apical, lateral, and mesial views. Scales: A-E, $1 \mathrm{~mm}$.

569

570 Figure 8. Phylogeny inferred from the partial mitochondrial DNA sequence of the 16S rDNA 571 gene. Note the sister taxon relationship between Fredius ibiapaba n. sp. and F. reflexifrons 572 (Ortmann, 1897).

573

574 Table 1 - Species of Fredius Pretzmann, 1967, Prionothelphusa Rodriguez, 1980 and

575 Trichodactylus Latreille, 1828 used in the phylogenetic analyses, with respective sample 576 locality, GenBank accession number and catalogue number of the voucher specimen.

577

578 Table 2 - Pairwise distance matrix from the portion of the mitochondrial 16S rRNA based on $579 \sim 560$ bp.

580

581 Table 3. Geographic and altitudinal distributions for the species of Fredius Pretzmann, 1967. 
Figure 1

Sítio Caranguejo, Ipú, Ceará, $04^{\circ} 18^{\prime} 50^{\prime \prime} \mathrm{S}, 40^{\circ} 44^{\prime} 47^{\prime \prime} \mathrm{W}, 729$ meters high, type locality of Fredius ibiapaba n. sp.

(A-E) Mid-altitude, naturally isolated, humid forested patch nested within the vast semiarid Caatinga domain. Note in (E) burrow (arrow) of Fredius ibiapaba n. sp. among the leaf litter. (E-F) Lowland, surrounding semiarid Caatinga forest. (E) View from above from Ipú. (F) Detail of a dry-stream channel. 


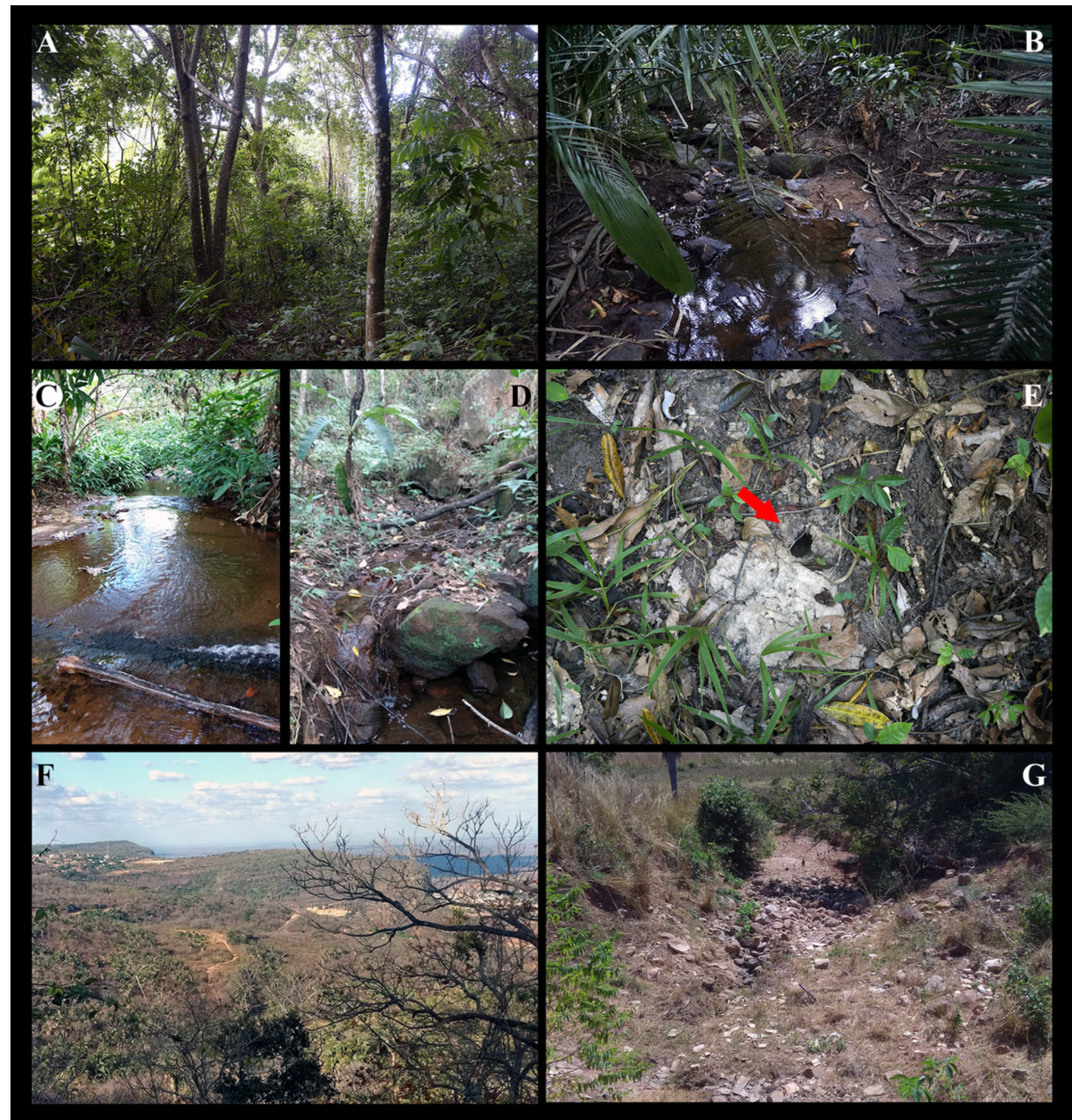


Figure 2

(A-B) Semi-diagrammatic view of the first male gonopod in abdominal and sternal views, respectively, with the terminology used in the descriptions.

$\mathrm{Cl}$, cephalic lobe; cs, cephalic spine; fas, field of apical spines; mal, marginal lobe; mas, marginal suture; mel, mesial lobe; sab, subapical bulge. 


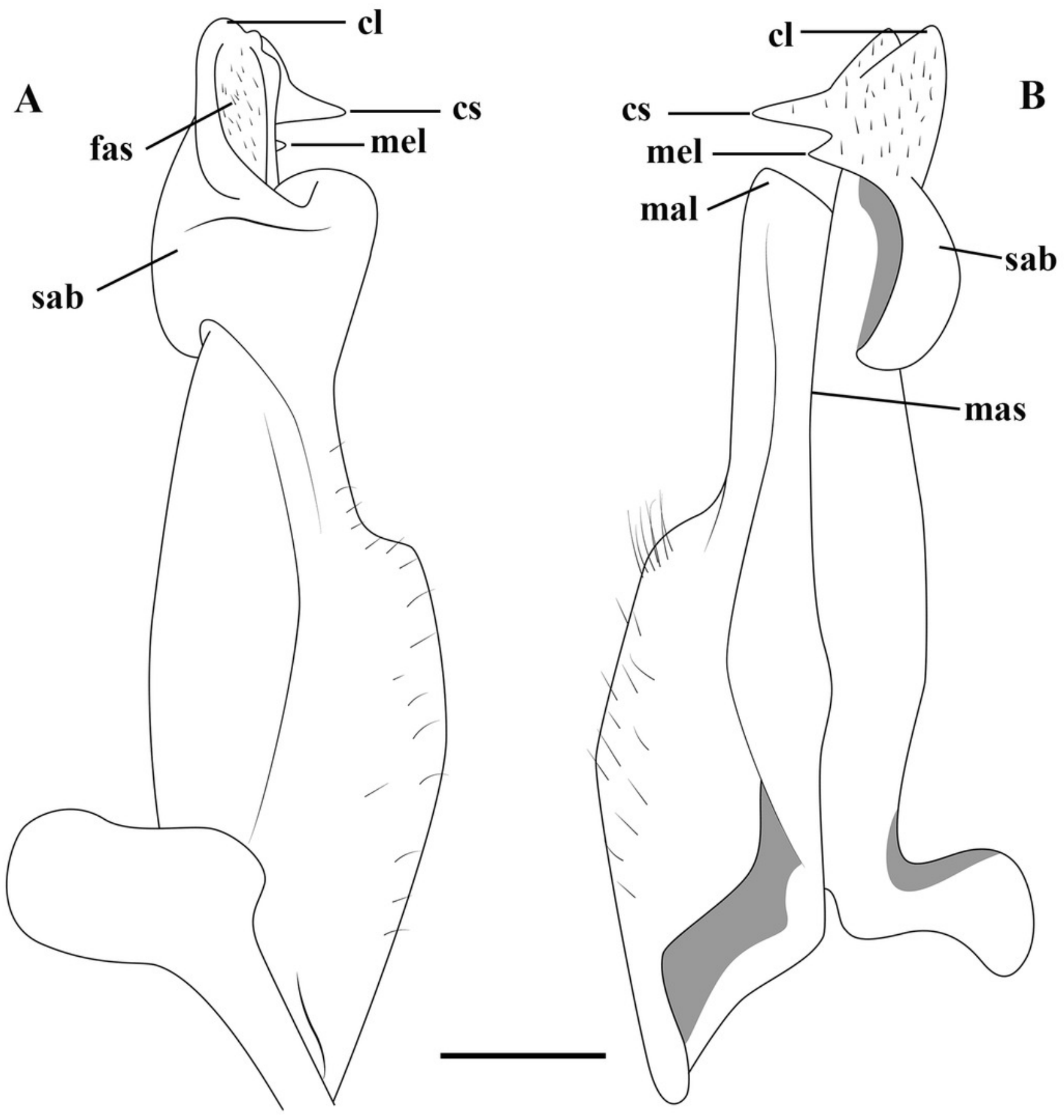




\section{Figure 3}

Fredius ibiapaba n. sp., male cl 36 mm, cw 53mm (MZUSP 39710).

(A-B) Habitus, dorso and ventral views, respectively. (C) Cephalothorax, frontal view. (D-E) Right and left chelipeds in lateral view, respectively. Scales: A-E, $10 \mathrm{~mm}$.

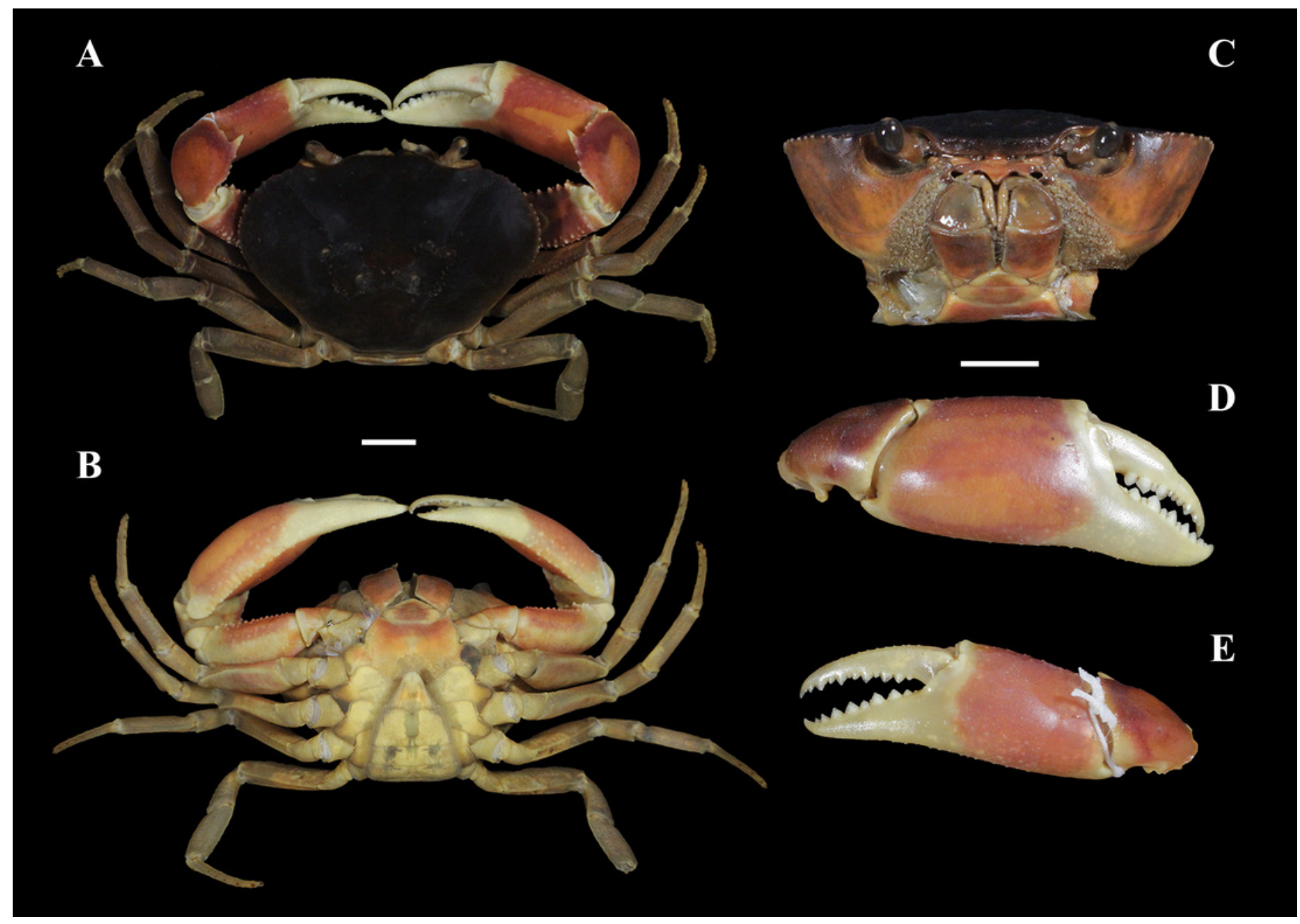




\section{Figure 4}

(A-F) Right male first gonopod (G1) in pleonal (tilted left), lateral and mesial views from $A-C$ and $D-F$, respectively.

(A-C) Fredius ibiapaba n. sp., holotype, male cl 36 mm, cw 53mm (MZUSP 39710). (D-F) Fredius reflexifrons (Ortmann, 1897), male cl 73.8 mm, cw 53 mm (MZUSP 13178). Note in $(B, C)$ the $\mathrm{Gl}$ remarkably swollen, sloping abruptly downwards anteriorly to a nearly rightangular shoulder (arrow), and in (E, F) the G1 shoulder clearly more gently sloping distally (arrow). Scales: A-F, $2 \mathrm{~mm}$. 


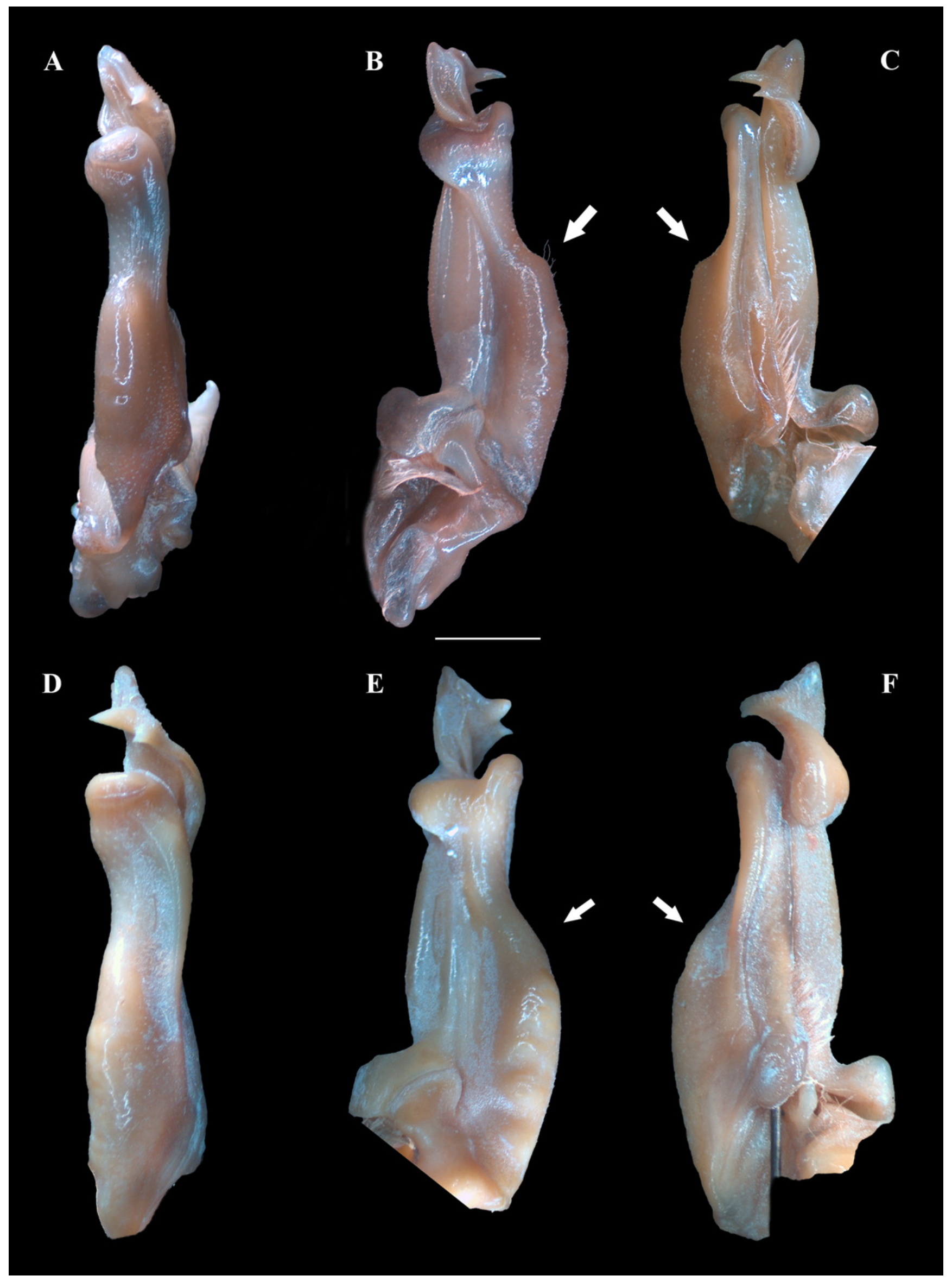




\section{Figure 5}

(A-D) Right male first gonopod (G1) in sternal and apical views from $A$ to $B$ and $C$ to $D$, respectively.

(A, C) Fredius ibiapaba n. sp., holotype, male cl 36 mm, cw 53mm (MZUSP 39710). (B, D) Fredius reflexifrons (Ortmann, 1897), male cl $73.8 \mathrm{~mm}, \mathrm{cw} 53 \mathrm{~mm}$ (MZUSP 13178). Note in (A) and (C) the G1 apex much less tilted so that the mesial lobe is not visible in sternal view (arrow), and the subapical bulge markedly less swollen (arrow), respectively. Note the opposite in (B) and (D). Scales: A-B, 2 mm; C-D, 1 mm. 


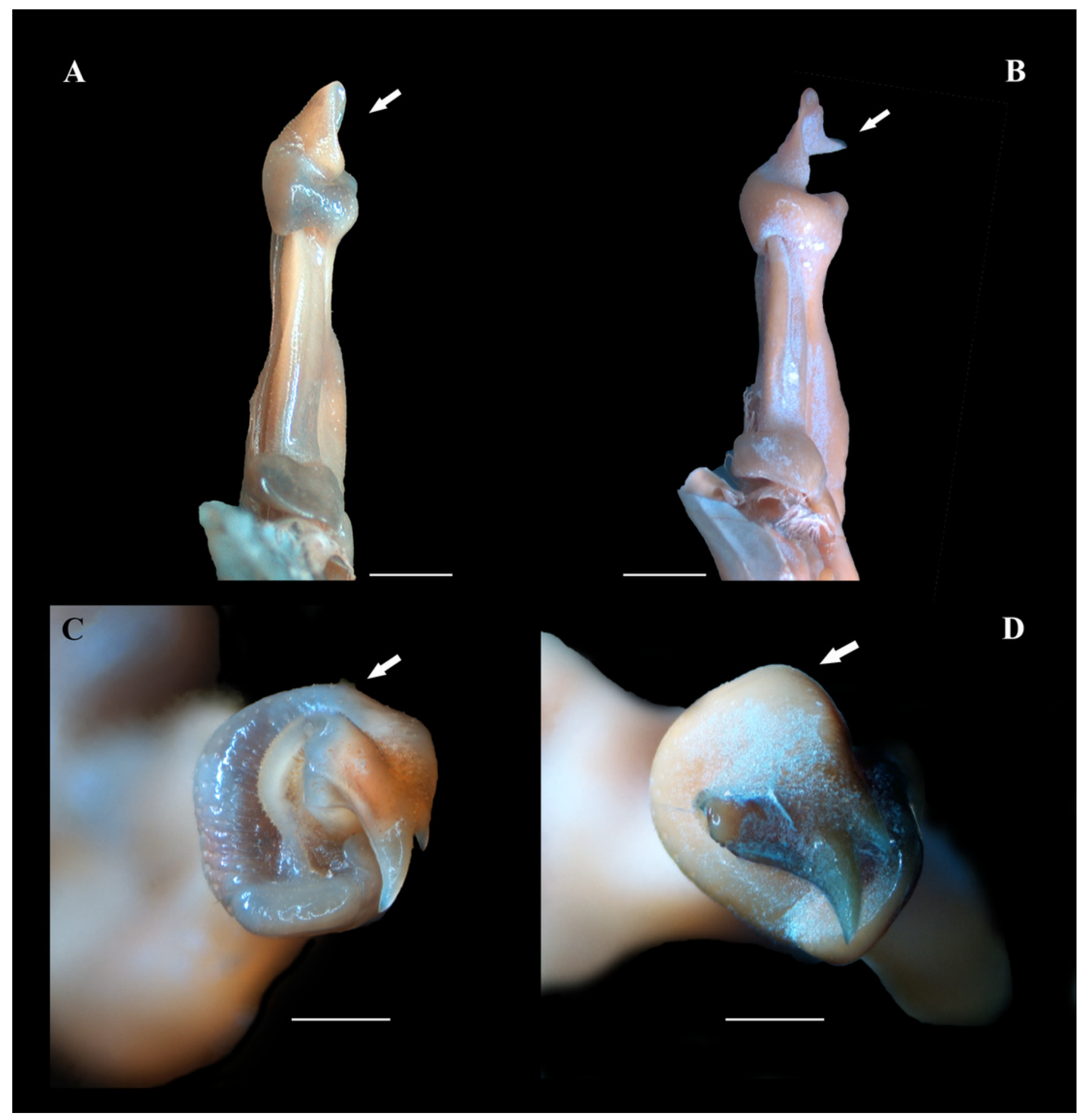


Figure 6

(A-H) Right male first gonopod (G1) in sternal, lateral, mesial, and pleonal views from A-D and $\mathrm{E}-\mathrm{H}$, respectively.

(A-D) Fredius ibiapaba n. sp., holotype, male cl 36 mm, cw 53mm (MZUSP 39710). (E-H)

Fredius reflexifrons (Ortmann, 1897), male cl 73.8 mm, cw 53 mm (MZUSP 13178). Scales: A-H, $1 \mathrm{~mm}$. 


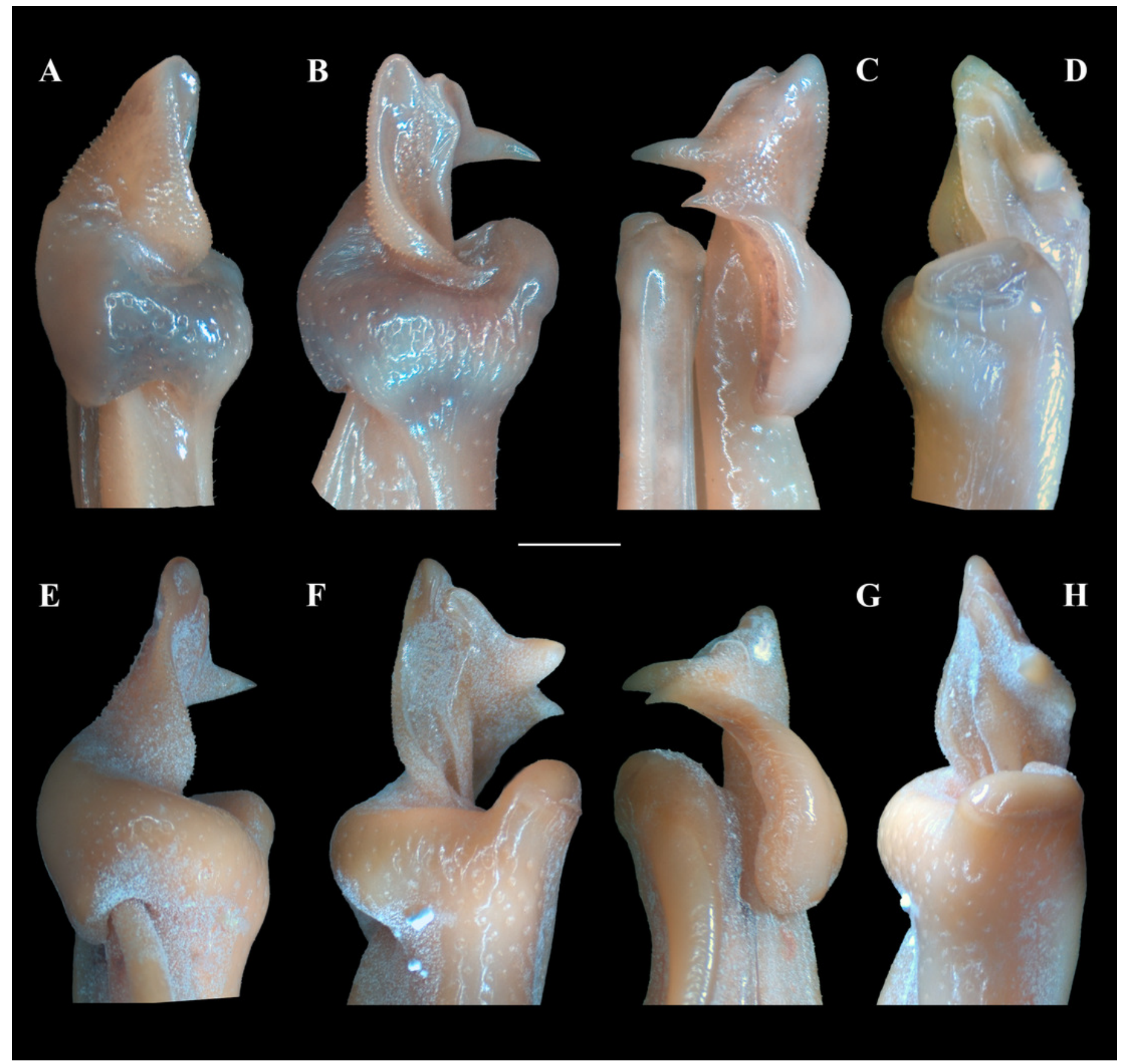




\section{Figure 7}

Fredius ibiapaba n. sp., paratype, male cl $41.2 \mathrm{~mm}$, cw $62.6 \mathrm{~mm}$ (MZUSP 39742). Scanning electron microscopy of the first right male gonopod.

(A) mesial (tilted right), (B) sternal, (C) apical, (D) lateral, and (E) mesial views. Scales: A-E, 1 $\mathrm{mm}$.

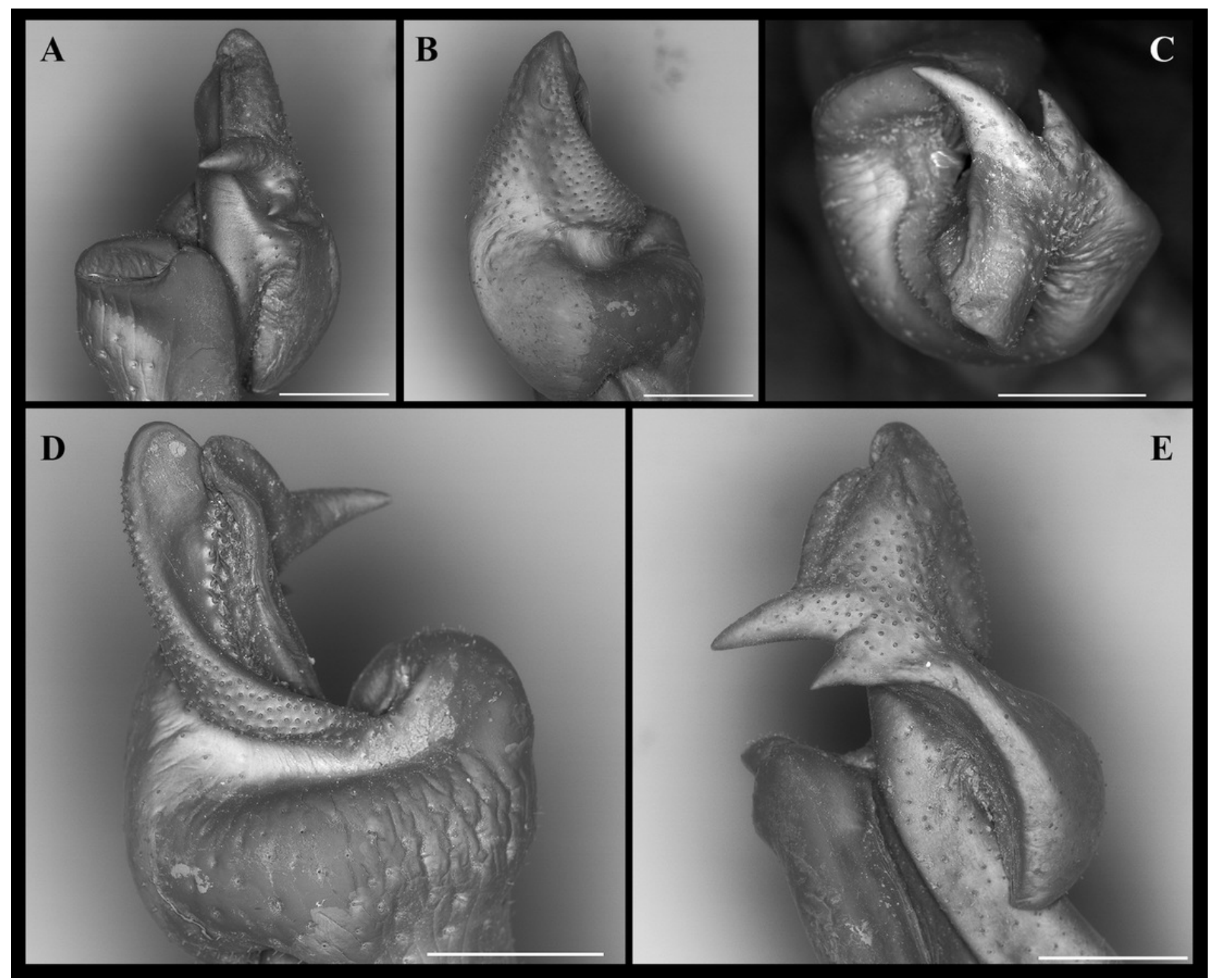


Figure 8

Phylogeny inferred from the partial mitochondrial DNA sequence of the 16S rDNA gene. Note the sister taxon relationship between Fredius ibiapaba n. sp. and $F$. reflexifrons (Ortmann, 1897).

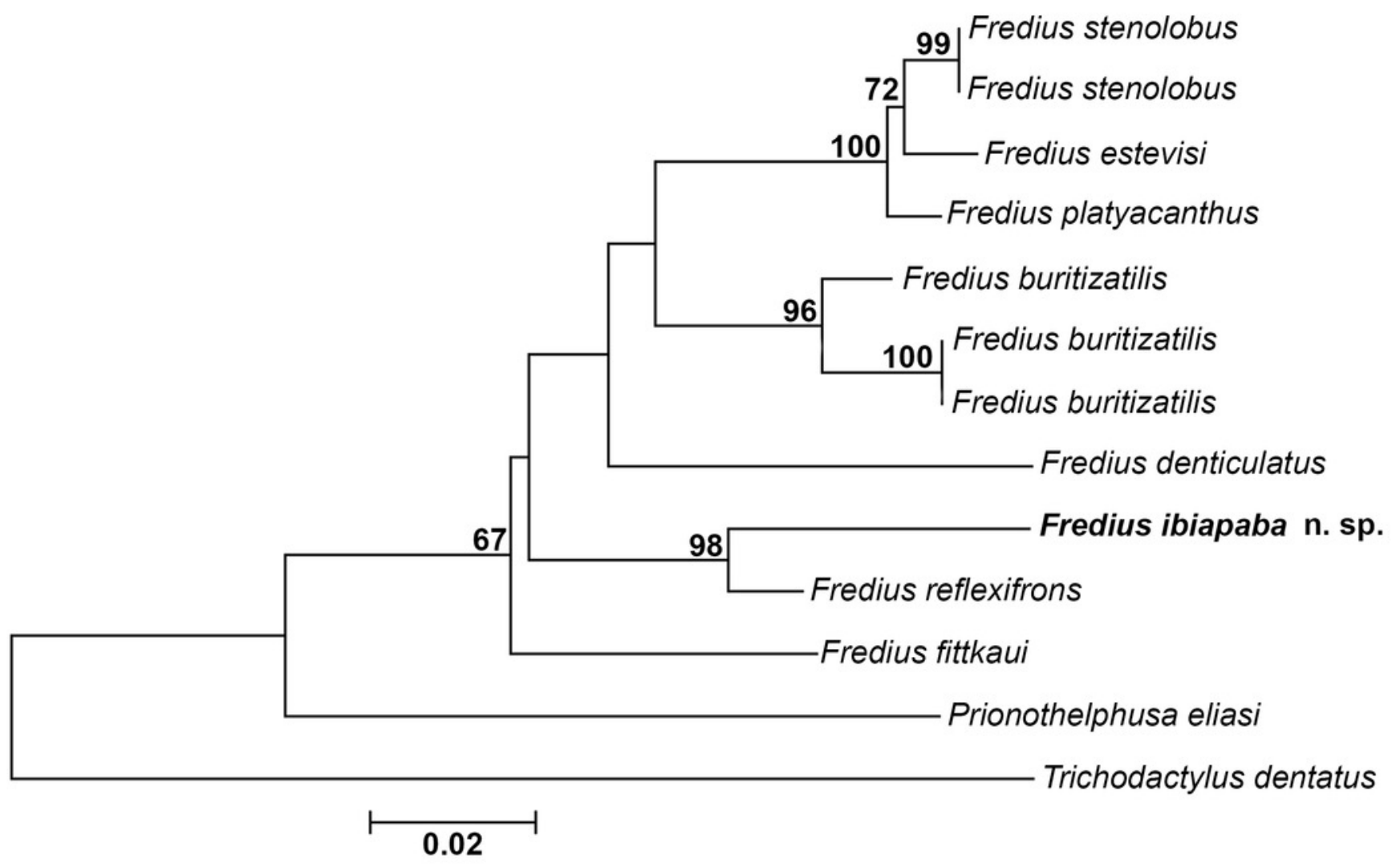




\section{Table $\mathbf{1}$ (on next page)}

Species of Fredius Pretzmann, 1967, Prionothelphusa Rodriguez, 1980 and Trichodactylus Latreille, 1828 used in the phylogenetic analyses, with respective sample locality, GenBank accession number and catalogue number of the voucher speci 
1 Table 1 - Species of Fredius Pretzmann, 1967, Prionothelphusa Rodriguez, 1980 and

2 Trichodactylus Latreille, 1828 used in the phylogenetic analyses, with respective sample

3 locality, GenBank accession number and catalogue number of the voucher specimen.

\begin{tabular}{llcc}
\hline Species & Locality & GenBank accession & Catalogue \\
& & numbers & number \\
\hline Fredius buritizatilis & Ji-Paraná, Rondônia, Brazil & JN402376 & INPA 1891 \\
Fredius buritizatilis & Ji-Paraná, Rondônia, Brazil & JN402377 & CCDB 342 \\
Fredius buritizatilis & Chupinguaia, Rondônia, Brazil & MN787136 & LACRUSE002 \\
Fredius denticulatus & Serra do Navio, Amapá, Brazil & JN402372 & INPA 582 \\
Fredius estevisi & Posto Indígena Parafuri, Roraima, Brazil & JN402379 & INPA 839 \\
Fredius fittkaui & Aldeia Balawa-ú, Amazonas, Brazil & JN402373 & INPA 1330 \\
Fredius platyacanthus & Comunidade Paapi-ú, Roraima, Brazil & JQ414023 & INPA 841 \\
Fredius ibiapaba n. sp. & Sítio Caranguejo, Ipu, Ceará, Brazil & MN787135 & LACRUSE001 \\
Fredius reflexifrons & Rio Chumucuí, Bragança, Pará, Brazil & JN402378 & INPA 1512 \\
Fredius stenolobus & Rio Tawadu, Bolívar, Venezuela & JN402374 & INPA 833 \\
Fredius stenolobus & Aldeia Palimi-ú, Rio Uraricoera, Roraima, Brazil & JN402375 & INPA 848 \\
Prionothelphusa eliasi & Japurá, Vila Bittencount, Amazonas, Brazil & MN787137 & LACRUSE003 \\
Trichodactylus dentatus & Bahia, Brazil & FM208777 & SMF 32763 \\
\hline
\end{tabular}


Table 2 (on next page)

Pairwise distance matrix from the portion of the mitochondrial 16S rRNA based on $\sim 560 \mathrm{bp}$. 
1 Table 2 - Pairwise distance matrix from the portion of the mitochondrial 16S rRNA based on $2 \sim 560 \mathrm{bp}$.

\begin{tabular}{|c|c|c|c|c|c|c|c|c|c|c|c|c|c|}
\hline & & 1 & 2 & 3 & 4 & 5 & 6 & 7 & 8 & 9 & 10 & 11 & 12 \\
\hline 1 & Fredius ibiapaba n. sp. & - & - & - & - & - & - & - & - & - & - & - & - \\
\hline 2 & Fredius reflexifrons & 0,04 & - & - & - & - & - & - & - & - & - & - & - \\
\hline 3 & Fredius burutizatilis & 0,10 & 0,07 & - & - & - & - & - & - & - & - & - & - \\
\hline 4 & Fredius buritizatilis & 0,11 & 0,08 & 0,02 & - & - & - & - & - & - & - & - & - \\
\hline 5 & Fredius buritizatilis & 0,11 & 0,08 & 0,02 & 0,00 & - & - & - & - & - & - & - & - \\
\hline 6 & Fredius denticulatus & 0,12 & 0,09 & 0,08 & 0,08 & 0,08 & - & - & - & - & - & - & - \\
\hline 7 & Fredius stenolobus & 0,10 & 0,07 & 0,07 & 0,06 & 0,06 & 0,10 & - & - & - & - & - & - \\
\hline 8 & Fredius stenolobus & 0,10 & 0,07 & 0,07 & 0,06 & 0,06 & 0,10 & 0,00 & - & - & - & - & - \\
\hline 9 & Fredius estevisi & 0,11 & 0,07 & 0,07 & 0,06 & 0,06 & 0,09 & 0,02 & 0,02 & - & - & - & - \\
\hline 10 & Fredius fittkaui & 0,09 & 0,07 & 0,07 & 0,07 & 0,07 & 0,09 & 0,08 & 0,08 & 0,08 & - & - & - \\
\hline 11 & Fredius platyacanthus & 0,10 & 0,07 & 0,06 & 0,06 & 0,06 & 0,09 & 0,02 & 0,02 & 0,02 & 0,08 & - & - \\
\hline 12 & Prionothelphusa eliassi & 0,16 & 0,13 & 0,12 & 0,12 & 0,12 & 0,13 & 0,12 & 0,12 & 0,12 & 0,13 & 0,12 & - \\
\hline 13 & Trichodactylus dentatus & 0,22 & 0,19 & 0,21 & 0,21 & 0,21 & 0,22 & 0,21 & 0,21 & 0,22 & 0,20 & 0,21 & 0,22 \\
\hline
\end{tabular}




\section{Table 3 (on next page)}

Geographic and altitudinal distributions for the species of Fredius Pretzmann, 1967. 
Table 3. Geographic and altitudinal distributions for the species of Fredius Pretzmann, 1967.

\begin{tabular}{|c|c|c|}
\hline Species & Country & Environment \\
\hline F. ykaa Magalhães, 2009 & $\begin{array}{l}\text { Brazil (Amazon River } \\
\text { basin) }\end{array}$ & Lowland streams \\
\hline $\begin{array}{l}\text { F. adpressus Rodriguez \& Pereira, } \\
1992\end{array}$ & $\begin{array}{l}\text { Venezuela (Orinoco River } \\
\text { basin) }\end{array}$ & Lowland streams \\
\hline F. beccarii (Coifmann, 1939) & $\begin{array}{l}\text { Brazil, Guyana, Venezuela, } \\
\text { Suriname (Essequibo- } \\
\text { Cuyuni Rivers basin) }\end{array}$ & Streams (igarapés) \\
\hline
\end{tabular}

F. buritizatilis Magalhães \&

Mantelatto, 2014

F. chaffanjoni (Rathbun, 1905)

F. cuaoensis Suárez, 2015

F. denticulatus (H. Milne Edwards, 1853)

$\begin{array}{ll}\begin{array}{l}\text { Brazil (Madeira River } \\ \text { basin) }\end{array} & \text { Buritizal (palm) fields } \\ \begin{array}{l}\text { Venezuela (Orinoco River } \\ \text { basin) }\end{array} & \begin{array}{l}\text { River's headwaters and mid- } \\ \text { courses }\end{array} \\ \text { Venezuela (Orinoco River } & \text { Highland streams } \\ \text { basin) } & \\ \begin{array}{l}\text { Brazil, Suriname, French } \\ \text { Guiana (Amazon and }\end{array} & \begin{array}{l}\text { Streams (igarapés) and along } \\ \text { Atlantic river basins) }\end{array}\end{array}$

\section{Altitude References}

(m)

36 to 73 Magalhães, 2009

100

50 to $752 \quad$ Rodriguez \& 1992

Rodriguez \& Pereira, Campos, 1998; Cumberlidge, Alvarez \& Villalobos, 2014; Mora-Day et al., 2009; Magalhães et al., 2014; Zanetti et al. 2018

$150 \quad$ Magalhães et al., 2014

105-300 Rodriguez \& Pereira, 1992

950 Suárez, 2015

70 to 400

Rodriguez \& Pereira, 1992; Rodriguez \&

Campos, 1998;

Magalhães et al., 2005; Magalhães, 2009; Cumberlidge, 


\begin{tabular}{|c|c|c|c|c|}
\hline & & & & $\begin{array}{l}\text { Alvarez \& } \\
\text { Villalobos, 2014; } \\
\text { Magalhães et al., } \\
2014\end{array}$ \\
\hline F. estevisi (Rodríguez, 1966) & $\begin{array}{l}\text { Brazil, Venezuela } \\
\text { (Amazon and Atlantic } \\
\text { rivers basins) }\end{array}$ & River's headwaters and streams & 446 to 944 & $\begin{array}{l}\text { Mora-Day et al., } \\
2009\end{array}$ \\
\hline F. fittkaui (Bott, 1967) & $\begin{array}{l}\text { Brazil, Venezuela, Guyana } \\
\text { (Amazon and Atlantic } \\
\text { rivers basins) }\end{array}$ & $\begin{array}{l}\text { Streams (iIgarapés) and along } \\
\text { river margins }\end{array}$ & 151 to 500 & $\begin{array}{l}\text { Rodriguez \& } \\
\text { Campos, 1998; } \\
\text { Magalhães \& } \\
\text { Rodriguez, 2002; } \\
\text { Cumberlidge, } \\
\text { Alvarez \& } \\
\text { Villalobos, 2014; } \\
\text { Magalhães et al., } \\
\text { 2014; Zanetti et al., } \\
2018\end{array}$ \\
\hline $\begin{array}{l}\text { F. granulatus Rodriguez \& Campos } \\
1998\end{array}$ & $\begin{array}{l}\text { Colombia (Amazon River } \\
\text { basin) }\end{array}$ & Lowlands & 180 to 200 & $\begin{array}{l}\text { Rodriguez \& } \\
\text { Campos, 1998; } \\
\text { Cumberlidge et al., } \\
2014 \text { Cumberlidge, } \\
\text { Alvarez \& } \\
\text { Villalobos, 2014; } \\
\text { Zanetti et al., 2018; }\end{array}$ \\
\hline $\begin{array}{l}\text { F. platyacanthus Rodríguez \& Pereira, } \\
1992\end{array}$ & $\begin{array}{l}\text { Brazil, Venezuela (Atlantic } \\
\text { rivers basin) }\end{array}$ & $\begin{array}{l}\text { Streams (igarapés) and } \\
\text { mountain areas }\end{array}$ & 106 to 1229 & $\begin{array}{l}\text { Rodriguez \& Pereira, } \\
\text { 1992; Cumberlidge, } \\
\text { Alvarez \& } \\
\text { Villalobos, 2014; } \\
\text { Magalhães et al., }\end{array}$ \\
\hline
\end{tabular}


F. reflexifrons (Ortmann, 1897)

F. stenolobus Rodríguez \& Suárez, 1994

Fredius ibiapaba n. sp.
Brazil, Venezuela,

Suriname, French Guaiana,

Peru, Guyana (Amazon

and Atlantic rivers basins)

Brazil, Venezuela (Orinoco Streams in rocky areas

River basin)

Lowland streams

Brazil (Orographic forest enclaves)
2014; Zanetti et al., 2018

37 to $200 \quad$ Magalhães \&

Rodriguez, 2002;

Magalhães et al., 2005; Cumberlidge,

Alvarez \&

Villalobos, 2014

65 to 1020 Rodriguez \&

Campos, 1998;

Magalhães \& Pereira, 2007; Cumberlidge,

Alvarez \&

Villalobos, 2014;

Magalhães et al.,

2014; Zanetti et al.,

2018

Burrows among the leaf litter,

665 to 782 Present study

water ponds inside forest stands or directly on the humid forest floor 